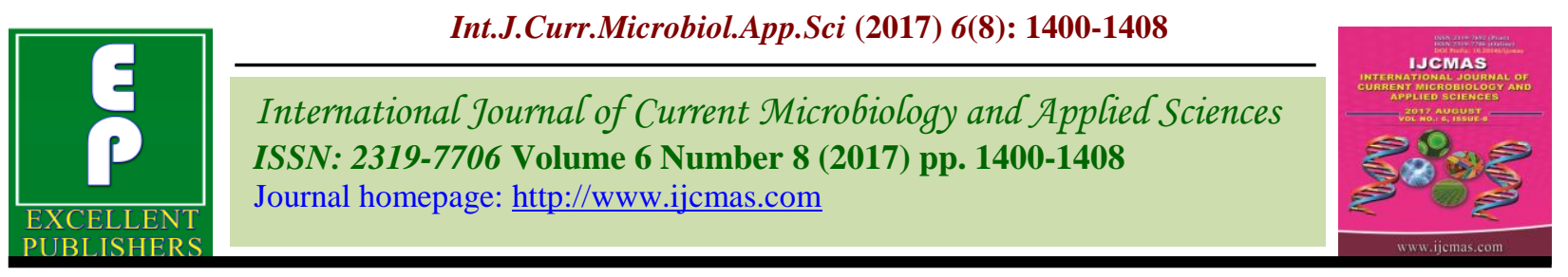

Original Research Article

https://doi.org/10.20546/ijcmas.2017.608.170

\title{
Rice Crop Response to Applied Copper under Varying Soil Available Copper Status at Tamilnadu, India
}

\author{
R. Angelin Silviya* and P. Stalin \\ Department of Soil Science and Agricultural Chemistry \\ Tamil Nadu Agricultural University, Coimbatore - 641 003, Tamil Nadu, India \\ *Corresponding author
}

A B S T R A C T

Keywords

Micronutrient,

Soil copper status,

Copper

fertilization, Rice growth and yield.

Article Info

Accepted:

17 June 2017

Available Online:

10 August 2017
The impact of graded levels of $\mathrm{Cu}\left(0,0.5,1.00,1.50,2.00,2.50 \mathrm{~kg} \mathrm{ha}^{-1}\right)$ on the growth and yield of irrigated rice was studied by conducting field experiments in major rice growing tracts having varied soil $\mathrm{Cu}$ status at Tamil Nadu. The treatment plots were replicated four times in Randomized Block Design. Application of $\mathrm{Cu} @ 1.5 \mathrm{~kg} \mathrm{ha}^{-1}$ recorded the highest plant height $(95.0 \mathrm{~cm})$, number of productive tillers $\mathrm{m}^{-2}$ (323.6), number of filled grains panicle $\mathrm{e}^{-1}(107.6)$, test grain weight $(24.5 \mathrm{~g})$, grain yield $\left(6.50 \mathrm{tha}^{-1}\right)$ and straw yield $\left(7.74 \mathrm{tha}^{-1}\right)$. The highest values were recorded in the location No.4 where the initial soil $\mathrm{Cu}$ content was minimum $\left(0.84 \mathrm{mg} \mathrm{kg}^{-1}\right)$. The results indicated that, the $\mathrm{Cu}$ fertilization significantly increased the growth and yield parameters of rice crop in $\mathrm{Cu}$ deficient soils while the soils with adequate or high $\mathrm{Cu}$ status showed declining response.

\section{Introduction}

The world's population is expected to hike about 9.7 billion by 2050 and the Indian population may increase to 1.6 billion from the current level of 1.2 billion (Shukla et al., 2014). Among the existing population, it has been reported that about 2 billion people of the world's population have been affected by micronutrient malnutrition. As anticipated, deficiencies of micronutrients are highly prevalent in places where cereals with low nutritional quality are the main diet (Cakmak, 2008). In order to feed the increasing population and to overcome the nutritional disorder, agricultural intensification is required which will improve the food production and it will meet out the dietary nutrient requirement of humans. More than half of the world's population consumes rice than other cereals (FAO, 2013). About 92 per cent of the world's rice are produced and consumed in Asia and among the Asian continent; India has the largest area of 29.4 per cent global area under rice cultivation (Humaira et al., 2015). In Indian states, Tamil $\mathrm{Nadu}$ stays third in the rice production (Mahata et al., 2012).

Micronutrients play a vital role in crop growth, crop productivity, soil fertility and human nutrition (Patel et al., 2015). Arnon and Stout (1939) proposed that, $\mathrm{Cu}$ is an essential element for plant growth. Among the 
micronutrients, $\mathrm{Cu}$ plays an important role in the crop growth by increasing the tillering and pollen viability of the crop (Das, 2014). Copper is a component of large number of proteins and enzymes like plastocyanin, diamine oxidase and ascorbate oxidases and $\mathrm{Cu}$ containing enzymes play an important role in photosynthesis, respiration and in lignin formation. It acts as a structural element in regulatory proteins and involves in photosynthesis electron transport, mitochondrial respiration, stress responses, cell wall metabolism and hormone signaling. The cereal crops show white tips as $\mathrm{Cu}$ deficiency symptoms and the deficiency of such micronutrient has been identified as the main limiting factor for crop yield, food quality and human health (Alloway, 2008).

Indian soils are extensively deficient in micronutrients and 5.4 per cent soils of India recorded $\mathrm{Cu}$ deficiency. The total $\mathrm{Cu}$ content in Indian soils ranged from 1.8 to $960 \mathrm{mg} \mathrm{kg}^{-1}$ and the available $\mathrm{Cu}$ content ranged from 0.10 to $378 \mathrm{mg} \mathrm{kg}^{-1}$. More than 25 per cent of $\mathrm{Cu}$ deficiency was recorded high in the soils of Tamil Nadu (Shukla et al., 2014). It reveals that, each essential nutrient has its own and specific role in the plant growth. Their presence in the required quantity is a must for completing the plant's life cycle. So, the rice crop also needs adequate amount of $\mathrm{Cu}$ for obtaining high yield which cannot be achieved by applying the NPK fertilizers alone. The soil survey, soil analysis and multi location trials will pave the way in enhancing the micronutrient content in the food crops by adopting location specific micronutrient recommendations. Keeping this in view, the present study was carried out.

\section{Materials and Methods}

The research work involved soil survey, soil sample collection, soil analysis and multi location field experimentations.

\section{Soil survey and analysis}

The soil survey was conducted in the major rice growing tracts of Tamil Nadu as Erode, Coimbatore, Tirunelveli and Tiruvarur districts. A sum of 144 surface soil samples was collected from the identified areas; they were processed and analyzed for various physico-chemical parameters. By following the International Pipette method (Piper, 1966) the textural classes of the soils were determined. The 1:2.5 soil-water suspensions were used to determine the $\mathrm{pH}$ of the soil by using $\mathrm{pH}$ meter and the EC through conductivity meter.

The Neutral Normal $\mathrm{NH}_{4} \mathrm{OAc}$ was used to determine the cation exchange capacity of the soil (Schollnberger and Dreibelbis, 1930). The available $\mathrm{N}, \mathrm{P}$ and $\mathrm{K}$ was determined through alkaline permanganate method (Subbiah and Asija, 1956), 0.5 M NaHCO (Olsen et al., 1954) and Neutral Normal $\mathrm{NH}_{4} \mathrm{OAc}$ method (Standford and English, 1949), respectively. The available $\mathrm{Cu}$ status in the soil was determined through DTPA extractable method proposed by Lindsay and Norvell (1978).

\section{Field experimentation}

The soils of four different districts (Erode, Coimbatore, Tirunelveli and Tiruvarur districts) of Tamil Nadu were categorized into six categories based on the soil available $\mathrm{Cu}$ status as $\leq 0.6,0.6-0.9,0.9-.12,1.2-1.5$, $1.5-1.8$ and $\geq 1.8 \mathrm{mg} \mathrm{kg}^{-1}$ of $\mathrm{Cu}$. The field experiments (two experiments per each category) were conducted in twelve locations to study the response of rice crop to the application of graded levels of $\mathrm{Cu}$ fertilizers $\left(0,0.5,1.0,1.5,2.0\right.$ and $\left.2.5 \quad \mathrm{~kg} \mathrm{ha}^{-1} \mathrm{Cu}\right)$. The experimental plots were designed by following Randomized Block Design with four replications. The rice variety ASD 16 was used as the test crop. 
In all the treatment plots, the NPK application was carried out uniformly by following the general recommendation as 150:50:50 kg ha of $\mathrm{N}, \mathrm{P}_{2} \mathrm{O}_{5}$ and $\mathrm{K}_{2} \mathrm{O}$. Nitrogen was applied in four equal splits as basal dose, active tillering, panicle initiation and heading stages. Entire dose of Phosphorous was applied as a basal dose. Potassium was applied in two equal splits as basal dose and at panicle initiation stage. The $\mathrm{Cu}$ fertilizer was applied in the form of $\mathrm{CuSO}_{4}$. Need based intercultural operations were carried out during the cropping period. In the experimental fields, the biometric observations (plant height and number of productive tillers per sq.m.), yield parameters (number of filled grains per panicle and test grain weight) and yield of grain and straw were recorded at harvest stage.

\section{Results and Discussion}

The results of the soil analysis, biometric observations and yield parameters of the experimental fields were recorded as follows:

\section{Soil analysis}

The soils of the experimental fields differed in their soil properties. The textural class of the study locations varied as sandy loam, sandy clay loam, clay loam and clay. The soils recorded neutral $\mathrm{pH}$ in a range of 6.50 to 7.85 . The EC of the experimental soils were free from soil salinity. The available $\mathrm{N}, \mathrm{P}$ and $\mathrm{K}$ of the soil fall under low - medium, medium and medium categories, respectively. The available $\mathrm{Cu}$ content in the soils ranged from 0.33 to $2.12 \mathrm{mg} \mathrm{kg}^{-1}$ of $\mathrm{Cu}$ (Table 1 ).

\section{Rice growth parameters}

Application of graded levels of $\mathrm{Cu}$ increased the height of the plants. In the fourth location (L4), the highest plant height of $94.1 \mathrm{~cm}$ was recorded (Table 2). The lowest plant height of
$89.3 \mathrm{~cm}$ was recorded in the first location (L1). Among the graded levels of $\mathrm{Cu}$ application, the $\mathrm{T} 4\left(1.50 \mathrm{~kg} \mathrm{ha}^{-1}\right.$ of $\left.\mathrm{Cu}\right)$ recorded the highest plant height of $95.0 \mathrm{~cm}$, the increase being 7.2 per cent over control (T1). Similarly, the application of $\mathrm{Cu} @ 1.50$ $\mathrm{kg} \mathrm{ha}{ }^{-1}$ recorded the highest productive tillers of $323.6 \mathrm{~m}^{-2}$, which showed a 24.6 per cent increase over control and the control $(-\mathrm{Cu})$ plots recorded the lowest productive tiller counts of $243.9 \mathrm{~m}^{-2}$ (Table 2). The fourth location recorded the highest number (315.4 tillers $\mathrm{m}^{-2}$ ) and the first location recorded the minimum number of tillers (248.9 tillers $\left.\mathrm{m}^{-2}\right)$.

The soils with low initial $\mathrm{Cu}$ status showed significant response to the $\mathrm{Cu}$ application which is in agreement with the findings of Liew et al., (2012) and Das (2014). Dobermann and Fairhust (2000) indicated that the active role of $\mathrm{Cu}$ in nitrogen, protein metabolism, hormone metabolism, photosynthesis, respiration and they were also involved in the auxin production which increased the vegetative growth of rice crop.

The rice growth got decreased by the application of $\mathrm{Cu}$ in the soils with high $\mathrm{Cu}$ content and the same result was recorded by $\mathrm{Xu}$ et al., (2005) which stated that the biomass responses to $\mathrm{Cu}$ were associated with its inhibition on photosynthesis, because excessive $\mathrm{Cu}$ could restrain chlorophyll synthesis or result in chlorophyll decomposition.

\section{Rice yield components}

The yield components such as number of filled grains per panicle and test (1000 grains) grain weight showed alike response to the $\mathrm{Cu}$ application (Table 3). An increase of 12.7 and 4.5 per cent of filled grains and test grain weight respectively over control was recorded by the application of $1.50 \mathrm{~kg} \mathrm{ha}^{-1}$ of $\mathrm{Cu}$ (T4). 
Table.1 Initial soil properties of various field experiments

\begin{tabular}{|c|c|c|c|c|c|c|c|c|}
\hline Locations & Soil texture & pH & $\begin{array}{c}\mathrm{EC} \\
\left(\mathrm{dSm}^{-1}\right)\end{array}$ & $\begin{array}{c}\text { CEC } \\
\left(\mathrm{Cmol}(\mathrm{p}+) \mathrm{kg}^{-1}\right)\end{array}$ & $\begin{array}{c}\text { Available N } \\
\left(\mathrm{kg} \mathrm{ha}^{-1}\right)\end{array}$ & $\begin{array}{c}\text { Available P } \\
\left(\mathrm{kg} \mathrm{ha}^{-1}\right)\end{array}$ & $\begin{array}{c}\text { Available K } \\
\qquad\left(\mathrm{kg} \mathrm{ha}^{-1}\right)\end{array}$ & $\begin{array}{l}\text { Available Cu } \\
\quad\left(\mathrm{mg} \mathrm{kg}^{-1}\right)\end{array}$ \\
\hline L1 & Sandy Loam & 6.54 & 0.14 & 13.2 & 389 & 18 & 197 & 0.33 \\
\hline L2 & Sandy Clay Loam & 6.55 & 0.15 & 17.3 & 185 & 20 & 128 & 0.53 \\
\hline $\mathbf{L 3}$ & Sandy Loam & 7.85 & 0.25 & 13.5 & 145 & 15 & 175 & 0.63 \\
\hline L4 & Sandy Clay Loam & 6.70 & 0.17 & 16.8 & 145 & 13 & 225 & 0.84 \\
\hline L5 & Sandy Clay Loam & 7.38 & 0.15 & 16.5 & 398 & 21 & 220 & 1.01 \\
\hline L6 & Clay & 7.52 & 0.12 & 21.8 & 158 & 15 & 270 & 1.11 \\
\hline L7 & Clay Loam & 7.40 & 0.18 & 15.8 & 130 & 17 & 272 & 1.28 \\
\hline L8 & Sandy Clay Loam & 7.50 & 0.23 & 17.2 & 182 & 12 & 235 & 1.33 \\
\hline L9 & Clay Loam & 7.55 & 0.25 & 15.2 & 192 & 13 & 165 & 1.57 \\
\hline L10 & Sandy Loam & 7.50 & 0.25 & 13.2 & 185 & 19 & 185 & 1.61 \\
\hline L11 & Sandy Clay Loam & 7.05 & 0.12 & 17.4 & 179 & 15 & 120 & 1.91 \\
\hline L12 & Sandy Loam & 6.50 & 0.17 & 13.5 & 198 & 14 & 142 & 2.12 \\
\hline
\end{tabular}


Table.2 Effect of $\mathrm{Cu}$ on plant height $(\mathrm{cm})$ and number of productive tillers $\mathrm{m}-2$ of rice crop at harvest stage

\begin{tabular}{|c|c|c|c|c|c|c|c|c|c|c|c|c|c|c|}
\hline $\begin{array}{c}\text { Cu levels } \\
\left(\mathrm{kg} \mathrm{ha}^{-1}\right)\end{array}$ & L1 & $\mathbf{L 2}$ & $\mathbf{L 3}$ & L4 & $\mathbf{L 5}$ & L6 & L7 & L8 & L9 & L10 & L11 & L12 & $\begin{array}{c}\text { Pooled } \\
\text { mean }\end{array}$ & $\begin{array}{c}\text { Per cent } \\
\text { over } \\
\text { control }\end{array}$ \\
\hline \multicolumn{15}{|c|}{ Plant height $(\mathrm{cm})$} \\
\hline 0.00 & 83.4 & 85.4 & 85.7 & 87.2 & 87.6 & 89.0 & 89.4 & 89.8 & 90.0 & 90.2 & 90.5 & 90.7 & 88.2 & - \\
\hline 0.50 & 86.2 & 88.0 & 88.3 & 90.7 & 90.4 & 89.7 & 89.9 & 90.2 & 90.5 & 90.8 & 93.1 & 93.0 & 90.1 & 2.1 \\
\hline 1.00 & 88.2 & 90.3 & 91.1 & 92.2 & 92.0 & 91.0 & 96.4 & 96.0 & 94.2 & 93.8 & 92.0 & 92.0 & 92.4 & 4.5 \\
\hline 1.50 & 94.5 & 96.4 & 97.5 & 99.8 & 99.2 & 98.2 & 93.5 & 93.4 & 92.5 & 92.2 & 91.8 & 91.6 & 95.0 & 7.2 \\
\hline 2.00 & 92.5 & 95.0 & 96.0 & 98.5 & 98.3 & 96.5 & 92.9 & 93.0 & 91.8 & 91.8 & 91.3 & 90.9 & 94.0 & 6.2 \\
\hline 2.50 & 90.7 & 91.2 & 95.4 & 96.3 & 96.0 & 95.0 & 92.5 & 92.2 & 91.2 & 91.5 & 90.7 & 90.9 & 92.8 & 4.9 \\
\hline Mean & 89.3 & 91.1 & 92.3 & 94.1 & 93.9 & 93.2 & 92.4 & 92.4 & 91.7 & 91.7 & 91.6 & 91.5 & & \\
\hline SEd & 0.63 & 0.8 & 0.52 & 0.91 & 0.89 & 0.78 & 0.52 & 1.05 & 0.89 & 0.76 & 0.69 & 0.45 & & \\
\hline CD $(5 \%)$ & 1.34 & 1.71 & 1.12 & 1.93 & 1.89 & 1.66 & 1.11 & 2.24 & 1.9 & 1.63 & 1.48 & 0.96 & & \\
\hline \multicolumn{15}{|c|}{ Number of productive tillers $\mathbf{~ m}^{-2}$} \\
\hline 0.00 & 176 & 192 & 214 & 234 & 230 & 252 & 251 & 256 & 273 & 278 & 284 & 288 & 243.9 & - \\
\hline 0.50 & 192 & 208 & 240 & 272 & 288 & 272 & 288 & 288 & 288 & 288 & 304 & 304 & 269.3 & 9.4 \\
\hline 1.00 & 251 & 272 & 293 & 304 & 320 & 272 & 324 & 320 & 320 & 304 & 288 & 288 & 296.4 & 17.7 \\
\hline 1.50 & 341 & 352 & 368 & 416 & 336 & 336 & 304 & 304 & 283 & 288 & 283 & 272 & 323.6 & 24.6 \\
\hline 2.00 & 277 & 288 & 320 & 363 & 320 & 320 & 288 & 288 & 288 & 272 & 288 & 272 & 298.7 & 18.3 \\
\hline 2.50 & 256 & 251 & 272 & 304 & 304 & 304 & 288 & 272 & 277 & 277 & 256 & 256 & 276.4 & 11.8 \\
\hline Mean & 248.9 & 260.5 & 284.5 & 315.4 & 299.7 & 292.7 & 290.5 & 288.0 & 288.1 & 284.5 & 283.8 & 280.0 & & \\
\hline SEd & 3.08 & 2.68 & 2.38 & 3.44 & 2.69 & 2.25 & 14.8 & 2.41 & 2.34 & 2.46 & 2.53 & 2.41 & & \\
\hline CD $(5 \%)$ & 6.57 & 5.71 & 5.08 & 7.32 & 5.69 & 4.79 & 31.5 & 5.14 & 4.99 & 5.24 & 5.38 & 5.13 & & \\
\hline
\end{tabular}


Table.3 Effect of $\mathrm{Cu}$ on number of filled grains per panicle and test grain weight $(\mathrm{g})$ of rice crop at harvest stage

\begin{tabular}{|c|c|c|c|c|c|c|c|c|c|c|c|c|c|c|}
\hline $\begin{array}{c}\text { Cu levels } \\
\left(\mathrm{kg} \mathrm{ha}^{-1}\right)\end{array}$ & L1 & $\mathbf{L} 2$ & $\mathbf{L 3}$ & L4 & $\mathbf{L 5}$ & L6 & L7 & L8 & L9 & L10 & L11 & L12 & $\begin{array}{c}\text { Pooled } \\
\text { mean }\end{array}$ & $\begin{array}{c}\text { Per cent } \\
\text { over } \\
\text { control }\end{array}$ \\
\hline \multicolumn{15}{|c|}{ Number of filled grains per panicle } \\
\hline 0.00 & 85 & 88 & 89 & 91 & 93 & 94 & 95 & 97 & 98 & 98 & 99 & 100 & 93.9 & - \\
\hline 0.50 & 94 & 96 & 97 & 100 & 99 & 97 & 97 & 96 & 93 & 91 & 106 & 104 & 97.5 & 3.7 \\
\hline 1.00 & 95 & 99 & 100 & 105 & 104 & 102 & 113 & 112 & 110 & 110 & 101 & 101 & 104.3 & 9.9 \\
\hline 1.50 & 102 & 106 & 108 & 116 & 114 & 113 & 109 & 109 & 108 & 105 & 101 & 101 & 107.6 & 12.7 \\
\hline 2.00 & 98 & 102 & 103 & 109 & 107 & 106 & 103 & 103 & 103 & 102 & 101 & 101 & 103.2 & 9.0 \\
\hline 2.50 & 97 & 100 & 102 & 107 & 105 & 105 & 100 & 100 & 102 & 102 & 100 & 100 & 101.7 & 7.7 \\
\hline Mean & 95.2 & 98.5 & 99.8 & 104.7 & 103.7 & 102.9 & 102.8 & 102.8 & 102.3 & 101.3 & 101.3 & 101.2 & & \\
\hline SEd & 0.87 & 0.86 & 0.94 & 0.73 & 0.87 & 0.96 & 0.71 & 0.61 & 1.02 & 0.74 & 0.87 & 1.11 & & \\
\hline CD (5\%) & 1.85 & 1.82 & 1.99 & 1.56 & 1.85 & 2.05 & 1.52 & 1.29 & 2.17 & 1.57 & 1.85 & 2.36 & & \\
\hline \multicolumn{15}{|c|}{ Test grain weight $(\mathrm{g})$} \\
\hline 0.00 & 23.0 & 23.1 & 23.2 & 23.3 & 23.4 & 23.5 & 23.6 & 23.6 & 23.6 & 23.6 & 23.7 & 23.7 & 23.4 & - \\
\hline 0.50 & 23.2 & 23.5 & 23.5 & 23.8 & 23.7 & 23.6 & 23.6 & 23.6 & 23.7 & 23.6 & 24.0 & 24.0 & 23.6 & 0.9 \\
\hline 1.00 & 23.8 & 24.0 & 24.2 & 24.6 & 24.4 & 24.0 & 24.6 & 24.5 & 24.3 & 24.1 & 23.7 & 23.6 & 24.1 & 2.9 \\
\hline 1.50 & 24.4 & 25.0 & 25.0 & 25.8 & 25.4 & 24.7 & 24.5 & 24.4 & 23.8 & 23.7 & 23.7 & 23.5 & 24.5 & 4.5 \\
\hline 2.00 & 24.1 & 24.1 & 24.4 & 25.0 & 24.7 & 24.2 & 23.7 & 23.6 & 23.7 & 23.6 & 23.6 & 23.5 & 24.0 & 2.5 \\
\hline 2.50 & 24.0 & 24.1 & 24.2 & 24.7 & 24.7 & 24.2 & 23.4 & 23.3 & 23.8 & 23.4 & 23.6 & 23.2 & 23.9 & 2.1 \\
\hline Mean & 23.7 & 23.9 & 24.1 & 24.5 & 24.4 & 24.0 & 23.9 & 23.8 & 23.8 & 23.7 & 23.7 & 23.6 & & \\
\hline SEd & 0.19 & 0.13 & 0.25 & 0.14 & 0.15 & 0.29 & 0.25 & 0.17 & 0.16 & 0.15 & 0.12 & 0.1 & & \\
\hline CD (5\%) & 0.41 & 0.28 & 0.53 & 0.29 & 0.32 & 0.61 & 0.52 & 0.37 & 0.34 & 0.31 & 0.25 & 0.22 & & \\
\hline
\end{tabular}


Table.4 Effect of $\mathrm{Cu}$ on the grain and straw yield $\left(\mathrm{t} \mathrm{ha}^{-1}\right)$ of rice crop

\begin{tabular}{|c|c|c|c|c|c|c|c|c|c|c|c|c|c|c|}
\hline $\begin{array}{c}\text { Cu levels } \\
\left(\mathrm{kg} \mathrm{ha}^{-1}\right)\end{array}$ & L1 & $\mathbf{L} 2$ & $\mathbf{L 3}$ & L4 & L5 & L6 & L7 & L8 & L9 & L10 & L11 & L12 & $\begin{array}{c}\text { Pooled } \\
\text { mean }\end{array}$ & $\begin{array}{c}\text { Per cent } \\
\text { over } \\
\text { control }\end{array}$ \\
\hline \multicolumn{15}{|c|}{ Grain yield $\left(\mathrm{t} \mathrm{ha}^{-1}\right)$} \\
\hline 0.00 & 3.85 & 4.05 & 4.16 & 4.38 & 4.45 & 4.58 & 4.63 & 4.70 & 4.77 & 4.84 & 4.98 & 5.07 & 4.54 & - \\
\hline 0.50 & 4.77 & 5.12 & 5.28 & 5.61 & 5.58 & 5.72 & 5.92 & 5.88 & 5.85 & 5.80 & 6.21 & 6.07 & 5.65 & 19.6 \\
\hline 1.00 & 5.97 & 6.21 & 6.38 & 6.25 & 6.00 & 6.38 & 6.68 & 6.60 & 6.44 & 6.38 & 5.60 & 5.45 & 6.20 & 26.8 \\
\hline 1.50 & 6.83 & 6.83 & 7.05 & 7.28 & 7.14 & 6.87 & 6.47 & 6.40 & 6.17 & 6.07 & 5.50 & 5.42 & 6.50 & 30.2 \\
\hline 2.00 & 6.55 & 6.70 & 6.80 & 6.98 & 6.93 & 6.66 & 6.40 & 6.25 & 5.92 & 5.85 & 5.32 & 5.28 & 6.30 & 27.9 \\
\hline 2.50 & 6.53 & 6.69 & 6.75 & 6.90 & 6.90 & 6.54 & 5.75 & 5.70 & 5.40 & 5.22 & 5.12 & 5.10 & 6.05 & 24.9 \\
\hline Mean & 5.75 & 5.93 & 6.07 & 6.23 & 6.17 & 6.13 & 5.98 & 5.92 & 5.76 & 5.69 & 5.46 & 5.40 & & \\
\hline SEd & 0.04 & 0.07 & 0.05 & 0.07 & 0.05 & 0.07 & 0.06 & 0.25 & 0.04 & 0.05 & 0.04 & 0.04 & & \\
\hline CD (5\%) & 0.08 & 0.16 & 0.11 & 0.15 & 0.10 & 0.14 & 0.13 & 0.53 & 0.09 & 0.12 & 0.09 & 0.09 & & \\
\hline \multicolumn{15}{|c|}{ Straw yield $\left(\mathrm{t} \mathrm{ha}^{-1}\right)$} \\
\hline 0.00 & 5.04 & 5.25 & 5.38 & 5.58 & 5.63 & 5.80 & 5.87 & 5.94 & 5.98 & 6.03 & 6.25 & 6.30 & 5.75 & - \\
\hline 0.50 & 6.04 & 6.35 & 6.52 & 6.84 & 6.80 & 6.97 & 7.14 & 7.12 & 7.08 & 7.04 & 7.42 & 7.33 & 6.89 & 16.5 \\
\hline 1.00 & 7.26 & 7.43 & 7.60 & 7.47 & 7.33 & 7.60 & 7.92 & 7.85 & 7.68 & 7.62 & 6.85 & 6.68 & 7.44 & 22.7 \\
\hline 1.50 & 8.07 & 8.22 & 8.29 & 8.48 & 8.34 & 8.11 & 7.72 & 7.62 & 7.40 & 7.30 & 6.72 & 6.63 & 7.74 & 25.7 \\
\hline 2.00 & 7.79 & 7.94 & 8.02 & 8.30 & 8.22 & 7.92 & 7.65 & 7.42 & 7.14 & 7.07 & 6.55 & 6.52 & 7.54 & 23.7 \\
\hline 2.50 & 7.72 & 7.90 & 7.95 & 8.14 & 8.12 & 7.78 & 6.98 & 6.95 & 6.65 & 6.45 & 6.32 & 6.32 & 7.27 & 20.9 \\
\hline Mean & 6.99 & 7.18 & 7.29 & 7.47 & 7.41 & 7.36 & 7.21 & 7.15 & 6.99 & 6.92 & 6.68 & 6.63 & & \\
\hline SEd & 0.05 & 0.05 & 0.08 & 0.06 & 0.16 & 0.05 & 0.06 & 0.06 & 0.08 & 0.05 & 0.04 & 0.06 & & \\
\hline CD (5\%) & 0.10 & 0.11 & 0.18 & 0.12 & 0.33 & 0.09 & 0.14 & 0.12 & 0.16 & 0.12 & 0.09 & 0.13 & & \\
\hline
\end{tabular}


In the fourth location, the highest number of filled grains per panicle (104.7) and test grain weight $(24.5 \mathrm{~g})$ was recorded. The number of filled grains per panicle was found low in the first location (L1) and the lowest test grain was recorded in the twelfth location (L12).

The yield of grain and straw was significantly increased with the application of graded $\mathrm{Cu}$ doses (Table 4). The fourth location which was with minimum initial soil $\mathrm{Cu}$ content recorded the highest yield of grain and straw (6.23 and $7.47 \mathrm{t} \mathrm{ha}^{-1}$ ), respectively. The lowest yield of grain and straw was recorded in L12, where the initial soil $\mathrm{Cu}$ status was high. Among different treatments, the treatment with $1.50 \mathrm{~kg} \mathrm{ha}{ }^{-1}$ of $\mathrm{Cu}$ (T4) registered the highest yield of 6.50 and $7.74 \mathrm{t}$ $\mathrm{ha}^{-1}$ of grains and straw respectively, and the yield increase being 30.2 and 25.7 per cent respectively over control was noted. The lowest mean yield was recorded in the control treatment with $4.54 \mathrm{t} \mathrm{ha}^{-1}$ of grains and $5.75 \mathrm{t}$ $\mathrm{ha}^{-1}$ of straw.

The positive effect of $\mathrm{Cu}$ on grain yield of rice observed in the present study might be attributed to enhancement of the pollen viability, grain formation and grain filling by improving the enzyme activities and the absorbed $\mathrm{Cu}$ increased the content of photosynthetic pigments in the plants resulting in the improvement of yield parameters of rice (Khush and Peng, 1996). They also stated that the translocation of carbohydrates produced in the leaves and stems into the grains were a pre-requiste for higher grain filling rate thus $\mathrm{Cu}$ helps in increasing the grain filling in rice crop. Similar findings were recorded by Dobermann and Fairhust (2000), Liew et al., (2012) and Das (2014). Due to the inhibition of photosynthesis caused by the excess $\mathrm{Cu}$ availability holds back the rate of chlorophyll synthesis and that decreased the yield of rice in the soils with higher soil $\mathrm{Cu}$ status ( $\mathrm{Xu}$ et al., 2005).
In conclusion, the findings of this study have shown that the application of $\mathrm{Cu}$ enhanced the grain and straw yields by 30.2 and 25.7 per cent increase over control. The yield increment was due to higher percentage increase of filled grains per panicle and test grain weight. The increase was noted due to the enhancement of photosynthesis metabolism which was promoted by the absorbed $\mathrm{Cu}$ ions by the crop. The study defines that, the soils with low initial $\mathrm{Cu}$ status responded positively to the application of $\mathrm{Cu}$ and the soils with high $\mathrm{Cu}$ status showed very less response to the $\mathrm{Cu}$ application. Therefore, it is concluded that, for obtaining higher yield in the $\mathrm{Cu}$ deficient soils $1.5 \mathrm{~kg} \mathrm{ha}^{-1}$ of $\mathrm{Cu}\left(6 \mathrm{~kg} \mathrm{CuSO}_{4} \mathrm{ha}^{-1}\right)$ may recommended.

\section{References}

Alloway, B.J. 2008. Zinc in soils and crop nutrition. Second edition, published by IZA and IFA, Brussels, Belgium and Paris, France.

Arnon, D.I. and P.R. Stout. 1939. The essentiality of certain elements in minute quantity for plants with special reference to copper. Plant Physiol., 4: 371-375.

Cakmak, I. 2008. Enrichment of cereal grains with zinc: Agronomic or genetic biofortification. Plant Soil, 302.

Das, S.K. 2014. Role of Micronutrient in Rice cultivation and management strategy in organic Agriculture - A Reappraisal. Agri. Sci., 5: 765 - 769.

Doberman, A. and T. Fairhurst. 2000. RiceNutrient Disorder and Nutrient Management $1^{\text {st }}$ Edition, Los Barios Laguna, IRRI and Singapore, Potash and Phosphate institute.

Food and Agricultural Organization (FAO). 2013. In feeding the world. FAO Statistical Yearbook. Retrieved January 7, 2013. 
Humaira, Tayeeb Samreen, Muhammad Javid, Muhammad Amin, Hmid, U. Shah, Saleem ullah and Sahib Alam. 2015. Effect of Zinc on Physicochemical Parameters of Hydroponically grown Rice Varieties. Middle East J. Agri. Res., 4(3): 395 - 403.

Khush, G.S. and S. Peng. 1966. Breaking the yield frontier of rice. In Reynolds MP, Rajaram $\mathrm{P}$ and McNab A (Eds.), Increasing yield potential in wheat: Breaking the barriers. Proceedings of a workshop held in Ciudad Obregon, Sonora, Mexico; Mar 26-28.

Liew, Y.A., S.R. Syed Omar, M.H.A. Husni, A.M.A. Zainal and P.A. Nur Ashikin. 2012. Effects of foliar applied copper and boron on fungal diseases and rice yield on cultivar MR219. Pertanika J. Trop. Agric. Sci., 35(2): 339-349.

Lindsay, W.L. and W.A. Norvell. 1978. Development of a DTPA soil test for zinc, iron, manganese and copper. Soil Sci. Soc. Am. J., 42: 421-428.

Mahata, M.K., P. Debnath and S.K. Ghosh. 2012. Critical limits of zinc in soil and rice plant grown in alluvial soils of west Bengal, India. SAARC J. Agri., 10(2): 137-146.

Olsen, S.R., C.V. Cole, F.S. Watanabe and A.L. Dean. 1954. Estimation of available phosphorus in soils by extraction with sodium bicarbonate. Circular No. 939, USDA.

Patel, K.S., S. Chikhlekar, S. Rameteke, B.L. Sahu, N.S. Dahariya and R. Sharma. 2015. Micronutrient status in soil of central India. American J. Plant Sci., 6: 3025 - 3037.

Piper, C.S. 1966. Soil plant analysis. Hans Publishers, Bombay.

Schollenberger, C.J. and I.R. Dreibelbis. 1930. Analytical methods in base exchange investigations in soil. Soil Sci., 30: 161-173.

Shukla, A.K., K. Pankaj Tiwari and Chandra Prakash. 2014. Micronutrients Deficiencies vis-à-vis Food and Nutritional Security of India. Indian J. Fert., 10(12): 94 -112.

Stanford, S. and L. English. 1949. Use of flame photometer in rapid soil tests of K. Canadian J. Agron., 4: 446 - 447.

Subbiah, B.V. and G.L. Asija. 1956. A rapid procedure for estimation of available nitrogen in soils. Curr. Sci., 25: 259260.

Xu Jia kuan, Yang Lian-xin, Wang Zi-qiang, Dong Gui-chun, Huang Jian - ye and Wang Yu long. 2005. Effects of soil copper concentration on growth, development and yield formation of rice (Oryza sativa), Rice Sci., 12(2): 125132.

\section{How to cite this article:}

Angelin Silviya, R. and Stalin, P. 2017. Rice Crop Response to Applied Copper under Varying Soil Available Copper Status at Tamilnadu. Int.J.Curr.Microbiol.App.Sci. 6(8): 1400-1408. doi: https://doi.org/10.20546/ijcmas.2017.608.170 